\title{
7 \\ Moral Refinement and Manhood in Persian
}

\author{
Mana Kia
}

In the mid-nineteenth century, under the pressures of looming European imperialism, Persians saw Iran's declining economic, social, and political position as the result of collective moral degradation. ${ }^{1}$ Justice had always been a central feature of the ideal of civilization, but it was in this period that it acquired the conceptual load of modern political discourse, requiring codified law and constitutional government. Justice as rule of law was seen as a necessary prerequisite for the rehabilitation of moral refinement that would restore Iran's place in the hierarchy of civilizations. Shame was a central emotion in these conceptual connections, linking individual moral abasement to the abrogation of political sovereignty. By the close of the nineteenth century, with the rise of mass politics and moveable type printing that enlarged the public sphere, emphasis began to shift to the centrality of individual moral refinement for the establishment of justice. In this formulation, older Persianate ideas of civility, of moral refinement as idealized masculinity, were linked to the restoration of civilization by extending the inviolability of masculine honour to the national body politic. Similarly, civility had always been conceptually embedded in ideas of moral refinement, but through the foregrounding of zeal and honour, it became inextricably linked to a decidedly national civilization.

This chapter first traces new concepts of civility and civilization articulated in Persian against the background of dominant ideas of the time. It then traces the changing labour these concepts performed, as arenas of discussion shifted from a small, literate elite to a broader audience in the context of increasingly mass movements around the turn of the twentieth century. The starting point is the first modernist tract (1859) where, drawing on older Persianate ideas, the justice necessary for civilization was posited as rule of law. During the constitutional period (c.1890-1912), Persian modernists foregrounded the cultivation of the individual as the means through which justice, increasingly posited as constitutional government, could be achieved. This shift was accompanied by calls for increased zeal and the preservation of shame in order to inculcate love and devotion to the nation, in the name of upholding masculine honour. Moral refinement was framed as the cultivation of a modern Iranian manhood.

This early elite language of reform negotiated itself by simultaneously drawing on and distinguishing itself from older Persianate ideals of just rule, virtuous conduct, and moral refinement. Persian had long been a transregional language of 
learning, power, and culture from Anatolia to Bengal, leaving the imprint of these ideas in languages such as Ottoman Turkish and Urdu. These ideas were not limited to the elite sphere, as many epics, stories, poems, moral exempla, scriptures, and various types of theological maxims were well known to those unable to read the written word via oral cultures of storytelling, recitation, and group reading practices (such as might occur in coffee houses). ${ }^{2}$ Thus, while the language of reform may have taken until the turn of the twentieth century to penetrate the popular public sphere, older ideas were far more dominant. As a result, the elite language of reform drew on these older ideas for legitimacy, even as it sought to refigure them.

Though many reformers engaged with European thought, they encountered this thought in largely indirect ways, through intermediate translations or engagement with neighbouring elites. Most elites were educated in at least Persian and Arabic, if not also Turkish and French. The first major moveable type presses to print Persian language books and newspapers were located in Istanbul and Cairo. The constant circulation of people, texts, and ideas between these places and Iran makes the ideas of the tanzimat (see Chapter 5, Ottoman Turkish) and nahda (see Chapter 6, Arabic) extremely important. Even less work has been done on links between Iran and India in spite of their shared Persian heritage up through the nineteenth century. ${ }^{3}$ By considering these more immediate contexts, many Persian conceptual entanglements with French and British thought also become about the locales and languages in which these encounters took place.

\section{PERSIAN TERMS AND CONCEPTS}

The basic way in which the cultivation of the individual was envisioned in the midnineteenth century was according to the training or refinement (tarbiyat or tahzib) of the twofold interrelated moral substance/state (akblaq) and manner/conduct $(a d a b)$. Conduct was a manifestation of moral substance, defying the notion of an inner state existing without its outer manifestation that had accrued to the modern English language concept of civility. ${ }^{4}$ The moral substance/proper conduct complex meant that an individual's moral substance could be altered through the cultivation of certain behaviours. In practice, this was not always the case, and an individual could, at one moment, display proper behaviour and, at the next, display improper behaviour. But this dissonance was a serial set of behaviours, and the idea of an inner state autonomous from outer behaviour was quite alien. This idea that individuals were, in substance, how they acted would also animate resistance to adoption of European-style reforms in the nineteenth century, since these were the practices of non-Muslim polities and peoples. ${ }^{5}$

The stylistic practice of alternating paired synonyms imbues words with semantic meaning. Certain words are semantically grouped through one of their meanings, which links the rest of their meanings and the words themselves to a particular concept. The seemingly obvious choice for civility, adab, means conduct, form, or manner. ${ }^{6}$ But other terms mean something similar and are used at least as often. 
Terms such as a'in (custom, rite), rasm (custom, manner, rule), or 'adat (customs, habits, manners) are also used in synonymous pairings with akhlaq, which is linked to $a d a b$ and its cognates through a shared meaning of 'manner/conduct'. This practice of synonymous pairings lays the concept's semantic field. Furthermore, the conceptual indivisibility of moral substance and behavioural manifestation in Persian is evident in the simultaneous meanings inhering in the terms that roughly correspond to civility: $a d a b$ and akblaq can both mean manners or morals.

In the context of older Persianate ideas, knowledge had long been the cornerstone of moral perfection, and was linked to ideas about the virtuous conduct of individuals and communities. This was because learning was thought to bestow the discernment necessary for the practice of moderation, the highest virtue. The archetypal community was envisioned as a city and, accordingly, its virtuous inhabitants defined by urbanity (madaniyat or tamaddun). Moderation, as the harmonious balance of all qualities, was the embodiment of moral refinement, known as equity (insaf) at the level of the individual and justice ('adalat) at the level of the community. The term vahshi referred to uncultivated states of wildness, savagery, and ignorance associated with the urbanite's opposite, the nomad, whose lack of education resulted in rudeness, ignorance, and excess. Virtue was also honourable masculinity, and savagery was described in words that also meant a lack of manhood. The virtuous man displayed chivalry (futuvvat or javanmardi)—defined by the qualities of bravery, generosity, courtesy, and honesty. Qualities and substances, virtuous or otherwise, are not the same as emotions. In Persian, moral states are categorized under varying degrees of virtues and vices, which can include feelings commonly grouped under the category of emotions in English and those that are not, such as equity.

Often a European concept was directly transliterated into Persian and then later fused with a Persian concept. By the mid-twentieth century, the Lughatnamah, the scholar and journalist Ali Akbar Dihkhuda's (1879-1956) important dictionary, lists madaniyat according to its old definition of city or urbanity. ${ }^{7}$ The specific flavour of urbanity is reflected in its other reference to Medina, which, as the site of the first Islamic community living under the Prophet Muhammad's rule, serves as the model of justice and virtue. ${ }^{8}$ Dihkhuda also links madaniyat to tamaddun, a word defined as 'the manner of the character (akblaq) of the inhabitants of a city: the transformation from roughness, uncouthness and ignorance to states of refinement, sociability, and learning' . 'Thus, tamaddun was at once the ideal of urbanity and the process by which one arrived at the qualities of such an ideal. By contrast, many late nineteenth-century writers used tamaddun and madaniyat interchangeably. In a secondary definition linking the two words as urbanity, Dihkhuda glosses madaniyat with the transliterated word civilisé, reflecting a fusion of Persianate urbanity with the French idea of being civilized. ${ }^{10}$ Before this early twentiethcentury fusion, French and English concepts of civilization existed uneasily alongside Persian ones. This unease was a product of cultural politics, whose debates refigured and redeployed the older concept of a morally refined urbanity, with its attendant ideas of just rule and virtuous manhood, to address the new challenges of European imperialism and civilizational hierarchy. 


\section{KNOWLEDGE, LAW, AND ORDER AS JUSTICE IN THE ELITE SPHERE}

After decades of Russian and British military and economic encroachment through the nineteenth century, most elites in Iran agreed there was a problem, but religious scholars, nobles, government officials, and various thinkers diverged on how to address it. ${ }^{11}$ Modernist writers preserved the status of knowledge as a prerequisite to the happiness and prosperity that were marks of a justly ruled kingdom, but sought to redefine what constituted knowledge itself. For some this was technological and administrative reform, and for others it was about deeper social and political changes, such as increased literacy and expansion of government control over areas traditionally the domain of the ulama (religious classes). ${ }^{12}$ The arts and sciences that had enabled Europe to advance in such a way to be able to threaten Iran's sovereignty needed to be adopted, though how was a severely contested issue. The semantic range of the oft-invoked term islah, sometimes used as reform towards European-style modernity and sometimes as renewal according to an Islamic ideal, is one indication of the highly varied and contested nature of concepts at this time. Some called for justice defined as monarchic rule through consultation, a familiar idea, with virtuous overtones echoing both the political practices of the early Islamic community and the figure of the wise minister in Persian political advice literature. ${ }^{13}$ For others, consultation more explicitly curbed the king's power in the form of a constitutional monarchy. Confusion over the meaning of terms had far-reaching political consequences in the course of the Constitutional Revolution (1906-11), such as a civil war (1908-09) and the crystallization of sharp political factions that continued to haunt Iranian society through the twentieth century.

In his Letters of Kamal al-Dawlah, Fath 'Ali Akhundzadah (1812-78), an Azeri atheist intellectual in Tbilisi, provides an explanation of a set of terms transliterated from European languages that demonstrate reformist terms of engagement. ${ }^{14}$ His first term is despot, defined as 'a king whose actions are not bound to any law and who exercises complete authority over the property and lives of the people without limit or restriction'. These are actions that manifest the particular state of such a king, who 'always behaves according to his own selfish desires (hava-yi nafs)'. The 'people under his rule, will be mean and contemptible slaves, and entirely excluded from the legal rights of freedom and humanity'. A ruler whose state is defined by the lusts of his base passions is one whose subjects are themselves reduced to base and contemptible states, rendering them outside the bounds of humanity.

According to Akhundzadah, the way out of this wretched state is civilization, defined as 'the salvation of a people from ignorance and savagery', through 'the attainment of necessary learning for the affairs of living, arriving at the degree of perfection in the sciences and arts, refining character (tahzib-i akhlaq) as much as possible, and manifesting excellence in the forms urbanity (adab-i tamaddun)' ${ }^{15}$ Civilization is not just the equivalent of tamaddun, rather it is morally elevated character manifested through excellence of urbane comportment, in opposition to 
the default state of ignorance and savagery. Such refinement comes from mastery of the arts and sciences, as well as the learning necessary for handling worldly affairs adroitly. Similarly, Akhundzadah defines progress as 'when men seek salvation from the state of ignorance and wildness and labour in the multitude of sciences, arts and beliefs which are necessary for advancement (taraqqi)'. ${ }^{16}$ This idea of advancement is one that means improvement with implications of hierarchy, though it came to explicitly mean civilizational progress.

Persian modernists attributed Iran's perceived backwardness and vulnerability to a lack of justice in government and society, and of individual equity. In Persian ethico-didactic literature, individual equity meant proper proportion of various qualities, and justice in the polity meant the order brought about by proper practice of power and administration. Justice and unity were linked, since 'lack of justice is the antagonistic plurality of extremes'. Unity was the balance of moderation, or the synthesis of extremes. ${ }^{17}$ The king was central to this idea of order. He was to sit above the polity and keep different groups in their proper place. Thus, good rulership resulted in justice and order, and its lack resulted in injustice and chaos. ${ }^{18}$ According to the norms of $a d a b$, in their calls for reformed administration, modernist texts extolled the king, reserving their attacks for government officials. Novel in these writings was that, without systemized laws and ordered administration, the ruler himself was not enough for justice to prevail in the kingdom. And without justice, there could be no safety for the kingdom, or peace, happiness, and or prosperity for the people. ${ }^{19}$

It is difficult to date many of the treatises, books, and articles discussed in this chapter since a number circulated first as manuscripts and/or lithographs. Many were later reprinted during the Constitutional Revolution, gaining wider readerships, and revitalizing their relevance to early twentieth-century public spheres. ${ }^{20}$ Mirza Malkum Khan (1833-1908), an Armenian convert to Islam who was educated in Paris and Istanbul and spent many years in Qajar diplomatic service, authored one of the earliest reformist tracts, 'Kitabchah-yi Ghaybi' (1859). ${ }^{21}$ The 'Kitabchah' was one of the first texts to articulate the importance of a codified body of law and regulated administrative procedure, clearly inspired by the Ottoman tanzimat. Circulated anonymously after the dismissal of the conservative chief minister, Mirza Aqa Khan Nuri, the 'Kitabchah' is addressed to the leaders of the government, painting a picture of a kingdom 'afflicted by [other] governments from all sides and bogged down in all kinds of baseness'. ${ }^{22}$ Malkum criticizes the negligence and lack of restraint that results in corruption and mismanagement, and notes that Nuri's resistance to change had been justified with the refrain that Fath Ali Shah (r. 1797-1834) had already established the proper balance of government. But Malkum argues that it has been more like five hundred, rather than just thirty, years since Fath Ali Shah's time: the historical and geopolitical changes in Asia, as well as Europe's technological advances, have made older ways of exercising government power obsolete. The world has quickened its pace of development and Iran has fallen out of temporal synchronicity with the rest of the world. ${ }^{23}$

To combat the imminent existential threat to Iran from the Russians and British, Malkum proposed new measures, which he claimed could not be found in Arabic 
terms, neighbouring polities, or ancestral models. Rather, 'what we need is science and perception' to discern new ways of legal and administrative order. The function of science was to enable the development of perception, a type of understanding located in the heart, for 'intellect (' $a q l)$ alone is not enough for governing in these times'. ${ }^{24}$ Needed were 'zeal (ghayrat) and statesmanship' to 'light a fire in the heart' of government officials. ${ }^{25}$ This call to cultivate zeal linked the kingdom of Iran's state to a crisis of honourable masculinity, which was also a crisis of morality. In sufficient quantities, zeal counteracted its opposite, negligence, and motivated the pursuit of science (systematized knowledge), which would give rise to the perception required to save Iran from collective abasement. But this call was limited to government elites alone.

Yik Kalamah (1870), written by the lifelong Qajar government servant Mirza Yusif Khan (d. 1895), presents a codified system of law as the basic principle necessary for Iran's progress. ${ }^{26}$ Like many other reformists, Yusif Khan frames his recommendations as derived from his experiences abroad in Russia, the Caucasus, Istanbul, France, and England, the latter two of which he presents as most accomplished in the attributes of civilization. He poses the problem, that if 'justice and equity are the foundations of the faith of Islam... why have we remained so backwards?' 27 The way to bring Iran within the 'circle of civilization' was to wake 'from the sleep of negligence', consider 'the state of advancement of other peoples', and undertake the necessary prerequisite transformations, otherwise the 'zealous leaders of Muslims', will be ashamed to give account of themselves on the Day of Judgement. ${ }^{28}$ Progress, order, and systemized law are posed in opposition to idleness, carelessness, and lethargy, and linked to states of masculine honour/dishonour. Significantly, shame is evoked as a deterrent to continuing negligence.

In Yik Kalamah, the sciences and arts, defined in technological terms, are the results of progress, and must not be confused with its prerequisite, which is qanun, or a codified system of all laws and procedures relating to worldly matters. It is systemization and standardization that defines qanun, not its specific content. In European countries, no single individual can act according to their own selfish desires in judicial and punitive matters because the people and the government together undertake this rule of law. ${ }^{29}$ Yusif Khan then argues that shari'a (divinely based law) should be similarly codified, so that the complementary religious and worldly law can function as intended. In an act of transplantational translation, he then introduces, interprets, and justifies aspects of the French Declaration of the Rights of Man as a worthy example of the worldly portion of codified law, using theological and juridical sources, such as the Qur'an and Traditions of the Prophet Muhammad. ${ }^{30}$ But in this reading of French law, the realm of worldly matters was far larger than was the case in Iran, eliciting staunch criticism from some ulama to this and similar proposals for legal reform. ${ }^{31}$ Properly codified law can guard against its abrogation, against injustice, by protecting it from the vagaries of base desires.

While some, like Malkum Khan and Yusif Khan, attempted to allay fears of compromising the Islamic character of Iran by finding Islamic roots for proposed 
European-style reforms, others, like Akhundzadah, created the basis of legitimacy for wholesale Europeanization in a pre-Islamic Iranian culture decoupled from and set in opposition to religion. Iran was isolated from 'world civilization' by the Arab invasion and supposedly forced conversion to Islam. This model of history, outlining an ancient 'golden age' followed by a slow decline commencing with the advent of Islam, reflected a new historical sensibility influenced by neo-Zoroastrian cosmology and Orientalist scholarship. ${ }^{32}$ For Akhundzadah, culture was racialized and Islam was the culture of the savage Arabs. The dissonance created by its imposition on the more refined Persians was what caused Iran's civilizational backwardness. ${ }^{33}$ Restoration of Iran's pre-eminent civilizational position required a cultivation of virtues that could not proceed without 'levelling the foundational beliefs of religion, which has become a curtain over the insight of people and prevented them from advancements in worldly matters'. ${ }^{34}$

Akhundzadah was nearly alone in posing Islam as an obstacle to progress, something many in his time understood to be an unabashed embrace of a European viewpoint. ${ }^{35}$ Muslim modernists such as Sayyid Jamal al-Din 'al-Afghani' (1838/39-1897) and Baha'i leaders like Mirza 'Abbas Nuri 'Abd al-Baha' (18441921) espoused the view that Islam was progressive. Both figures addressed transregional audiences and grounded their reformist ideas in a religion refigured through early nineteenth-century Shaykhi/Babi interpretations of the related illuminationist (ishraqi) and moral (akhlaqi) philosophy. ${ }^{36}$ They both take Persianate ideas of individual moral refinement and translate them into new concepts of civilization, which require the restraint of selfish desires and the cultivation of virtuous states.

Afghani is best remembered for his propagation of what has been called panIslamism, an ideology of resistance to European imperialism propagating selfstrengthening by recourse to a rationalist Islam under the banner of Muslim political unity. ${ }^{37}$ Afghani's most famous Persian treatise, Haqiqat-i Mazhab-i Naychiri va Bayan-i Hal-i Naychiriyan (The truth about the naturist sect and an explanation of their state) was composed after his encounter with Sayyid Ahmad Khan's (see Chapter 8, Urdu) followers in Hyderabad (1880-82). ${ }^{38}$ The treatise outlines three beliefs and three qualities produced by religion, which together formed the 'six-sided castle of human happiness' that was the foundation of civilization. ${ }^{39}$ The first belief is that man is the noblest of creatures, which resulted in his 'disdain for bestial qualities'. The more this disdain took hold, the greater the individual's progress in the intellectual sphere, which was a measure of his 'ascent on the ladder of civilization'. At the top of this ladder are 'civilized, virtuous men whose life with brothers who have reached this rung of civilization is based on love, wisdom and justice', an arrangement that is 'the summit of human happiness'. ${ }^{40}$ The second belief is 'the certainty that his community is the noblest one' and that all others are 'in error and deviation'. This belief manifested the result that the individual will 'enter into rivalry and competition with other communities' in intellectual, spiritual, and material virtues. Unlike beasts who do not strive to change or improve themselves, 'such an individual will never be satisfied with decline, baseness, or ignobility for himself and his community'. This belief protected 
against apathy, described as a lack of striving and a weakness in zeal, which, unchecked, would result in 'slavery, humiliation and abasement'. The third belief is that there is a Day of Judgement, which caused the individual to 'always strive to improve and enlighten his mind with true science and sound knowledge'. This last belief is 'the best impulse toward civilization, whose foundations are true knowledge and refined morals' and 'the best requisite for the stability of the social order'. Because the pursuit of moral refinement requires 'truthful and honest observation of the bounds of human intercourse', this belief is the motive for peaceful and amiable international relations. ${ }^{41}$

The first quality produced by religion, shame ( haya'), is fundamental to the social order, because it prevents men from 'committing acts that would cause foulness and disgrace', and instils a 'reluctance to take on qualities that are considered to violate the world of humanity'. Shame heralds awareness of the nature of virtues, and motivates the proper conduct to manifest them. Shame is the 'basis of good order in human relations' and, without it, the two other qualities, trustworthiness and honesty, cannot exist. It is necessary for the 'bond of human alliances, associations and societies, since an alliance within a group takes place only when the rules are maintained', which shame ensures. Shame is also critical because it generates pride or zeal, two characteristics that 'are the cause of the progress of nation', without which a community would 'forever remain in a state of lowliness, baseness, humiliation, poverty and subjection'. ${ }^{42}$ For Afghani, shame is the antithesis of humiliation, because it signals the presence of discernment and generates zeal towards the pursuit of virtue.

In contrast, regardless of their diverse roles, Naychiris undermined religion's beliefs and qualities by seeking to set aside social hierarchies and laws, causing shame to disappear. This would lead to the moral degradation of individuals and society and eventually to political conquest. Afghani defined Naychiris as those who only believed in the material world, appearing as secularists, heretics, reformers, mystics, or revolutionaries. Such a definition linked classical tropes of chaos-inducing heretics with the particular type of modernizing reformer who advocated cultural emulation of Europe. ${ }^{43}$

'Abd al-Baha, the eldest son and successor of Bahullah, founder of the Baha'i religion, anonymously authored Risalah-yi Madaniyat (1875). ${ }^{44}$ Drawing heavily on Arab and Ottoman reformists (see Chapters 5, Ottoman Turkish, and Chapter 6, Arabic), such as Rifa'a al-Tahtawi and Namik Kemal, he outlines a complex relationship between religion and progress. ${ }^{45}$ In addition to the Qur'an and Traditions, 'Abd al-Baha draws on a wide variety of sources in keeping with his universalist message, such as the Bible, pre-Islamic Persian history, Persian literature, Greek history, and the works of the Shi'i Imam 'Ali and the American intellectual, John William Draper. While 'Abd al-Baha advocated the adoption of some European and Japanese scientific and social reforms, he characterizes European culture as superficial and morally bankrupt because of Europe's constant warfare and imperialist aggression. He argued that partial borrowing from Europe would not compromise the Islamic character of Iran, since 'most of the civilization (tamaddun) of Europe is derived from Islam'. ${ }^{46}$ 
Written in response to the modernization efforts of the early 1870 s, the Risalah specifically evokes the idea of renewal (islah): that in every age mankind will refine his community using reason and knowledge. ${ }^{47}$ As with Afghani, the centrality of knowledge to this renewal reflects the influence of Persian illuminationist philosophy that prized the intellect. ${ }^{48}$ The Risalah frames Islam's divinely illuminated knowledge as responsible for the transformation of the wild inhabitants of Mecca and Medina from a state of ignorance to a state of learning, so that 'they shone like stars of happiness and civilization and became the centre of arts, wisdom, sciences, and human perfection'. Individual moral reform undertaken for the greater good is the basis of community progress in the Risalah. Virtues derived from new 'useful' knowledge and reformed religion were to be the engine for this progress. With faith and education, the Iranian nation could reform itself by making progress towards a just society. The end point is a vision similar to other reformers, by the end of which Iran would (once again) be the 'world-revealing mirror of world civilization (madaniyat)'. ${ }^{49}$

The Risalah describes perfection as the acquisition of science and knowledge, existence of justice, and selflessness in the cause of educating the populace. ${ }^{50}$ This perfection is built on particular qualities specific to people of faith, such as equity, compassion, generosity, truthfulness, sincerity, trustworthiness, love, courtesy, zeal, and humanity (insaniyat). ${ }^{51}$ The control of the passions (hava), whose cultivation in the proper amounts results in a balance, produces these moral qualities (akhlaq). Such continuous cultivation is important because even the most perfect individual can be driven to abasement by 'following their passions until their pleasing qualities leave the form of moderation and are cast into the region of excess' ${ }^{52}$ Thus, a prerequisite of civilization was a careful cultivation of particular qualities, manifest through proper conduct to preserve temperance (itidal).

For 'Abd al-Baha, the learning of civilization was a mobile light, available for the benefit of everyone, both in Europe and Asia, East and West. 'Abd al Baha's equation of learning with light was something shared with other nineteenth-century writers. ${ }^{53}$ For Malkum Khan, Iran was merely uninformed of methods of executing its law that 'world progress' had invented after much trial and error. ${ }^{54}$ Drawing on Auguste Comte (1798-1857), Malkum Khan understood progress as civilization itself, echoing Comtean positivism's motto of 'love as principle, order as basis, progress as end'. Comte's emphasis on science as a necessity to achieve order and then progress, was a notion also intelligible in older Persianate terms. ${ }^{55}$ This selective adoption of ideas interpreted in ways that resonate strongly with Persianate concepts is a hallmark of modernist writing. ${ }^{56}$

In conservative nineteenth-century court and clerical circles, authority was considered split between the rulers and the 'ulama, who were interdependent purveyors of order and knowledge, respectively: 'The mutual enemies of both Shah and 'ulama were the seditious within and aggressors without.' ${ }^{57}$ Traditionally, the archetypal seditious figure was the heretic, while the aggressor was the tribal nomad. From the mid-nineteenth century, the figure of the 'Babi, real or 
imagined', became synonymous with the heretic. ${ }^{58}$ After the Babi Movement declared itself a new religion, led an armed uprising against the Qajar state, and attempted to assassinate the Shah, accusations of religious heresy became associated with political radicalism. ${ }^{59}$ Republican ideals were associated with fitnah, or the sedition of irreligion and socio-political chaos. ${ }^{60}$ Thus, from the very beginning, representative government was associated with the ignoble and terrifying repercussions of fitnah, backlit by the Babi uprisings and their ongoing repression.

Because the concept of justice was so tied to order, even modernist writers regarded the Babis/Baha' is as a threat to unity, order, and reason. Akhundzadah saw religion as antithetical to reason due to the ostensibly superstitious nature of its beliefs and practices, with Babism as a recent manifestation of such fanaticism. ${ }^{61}$ He explicitly evokes Thomas Buckle (see Chapter 2, Great Britain), Voltaire, and Ernest Renan (see Chapter 3, France) in linking religion, oppression, and backwardness. ${ }^{62}$ Akhundzadah contended that Europe's freedom of expression engendered rational debate, which deterred the formation of irrational movements like Babism. ${ }^{63}$ Malkum Khan characterized the Babis as a 'blind movement in the crowd', that resulted in nothing but bloodshed. ${ }^{64}$ Afghani explicitly linked Babis to Naychiris, whom he described as creating moral corruption and social chaos, leading to political enslavement and civilizational dissolution. Even in term of counter-concepts, older Persianate ideas of individual virtue were used to craft new concepts of civilization that were indigenized, built on the scaffolding of older political ethics of justice and order.

\section{INDIVIDUAL CULTIVATION IN THE GROWING PUBLIC SPHERE}

Nineteenth-century modernists called upon the valorized masculine qualities of zeal, devotion, and lofty aspiration (himmat) to mobilize their audiences towards action. Calls to cultivate lofty aspiration were part of a broader appeal for a self-sacrificing civic ethic to engender collective progress towards justice. Lofty aspiration was set directly in contrast to the loathsome behaviour of selfishness, a sign of being ruled by one's uncontrolled passions. To achieve lofty aspiration, one needed to cultivate zeal in the proper amount and to the right end; lack of zeal resulted in debased manhood and was generally perceived to be one cause of Iran's civilizational backwardness. Increasingly, these terms took on a nationalist tone, as the millat, previously a religiously defined community, became the Iranian nation, whose members were distinguished by their devotion to and love of homeland. ${ }^{65}$ Shame at the lack of zeal was invoked to generate the moral refinement necessary to recoup a rearticulated concept of masculine honour.

The emphasis on the individual was not entirely new but became dominant during the constitutional period (1890-1912). Earlier, Akhundzadah had argued that it was incumbent on 'the wise ones of the community', to restore 'the excellence of the people and the guardianship of the homeland ... by repelling that kind 
of baseness that is the product of the imprisonment and deprivation of freedom'. Baseness was repelled through:

propagation of the sciences all through the equity of the people and sowing of the seed of zeal, honour (namus), fellow-feeling, and service to the homeland in the field of their mind's thoughts, since all of these qualities are attributes of manliness and chivalry, so much so that the powerful nations of Europe at this time are endowed by these qualities. ${ }^{66}$

Calls to the Iranian people need to be understood in this light, as made to the elite to guide the reform of the people. This was an old logic; it was the reference points of these qualities that were new. Akhundzadah calls for the cultivation of zeal to protect the self and the community. Namus, a specific kind of masculine honour dependent on the chastity of one's women, gave this protection meaning by connecting self and community. By the constitutionalist era, individual masculine honour was linked to the honour of the national community through this principle of inviolateness, and political reform in the defence of sovereignty became an act of masculine virtue. ${ }^{67}$

This shift in emphasis coincided with the rise of mass politics in Iran. In 1890, Nasir al-Din Shah granted a British company a monopoly on the purchase of indigenous tobacco and the sale of tobacco products in Iran. In response, mass political mobilizations inside and outside of Iran resulted in a boycott of tobacco, forcing the Shah to repeal the concession in 1892. The Tobacco Protests also resulted in the formation of secret societies and brought together 'ulama, reformers, merchants, and common people for the first time, in ways which would be repeated and expanded upon during the Constitutional Revolution. ${ }^{68}$

Malkum Khan's dissident newspaper, Qanun (1890-98), commented on the Tobacco Protests, presenting an ideal patriot as one who did not relinquish his country to the sensual pleasures (hazz-i nafs) of others. ${ }^{69}$ Not knowing that the land of Iran belonged to its inhabitants resulted in 'not only the silent acceptance of all manner of oppression and disgrace', but a situation in which people 'fall to the dirt before any unmanly/ignoble leader and confirm in a thousand types of womanly ways that the servants of that leader "have particular right to whatever we have-possessions, life, honour"'. They have 'only recently become aware that this is not how the justice and law of God works'. ${ }^{70}$ The protection of one's own country was presented as part of the maintenance of masculine honour and part of a divinely sanctioned order. By the late nineteenth century, the kingdom of Iran was envisioned as both a mother to protect and a beloved to possess, on whose behalf its male citizens must strive. ${ }^{71}$ Civility and the subject of civilization were thus specifically masculine, constituted through possessing and protecting. Qanun further elaborated that the Tobacco Protests taught Iranians that 'the real possessors of this land are the people of this land', and this knowledge had caused 'the sound of adamiyat to grow ever louder in all provinces of Iran'. ${ }^{72}$ Adamiyat is commonly translated as humanity, but it is clear that Malkum Khan meant mankind, since a quality of adamiyat is manliness (mardanigi). Women are discussed as objects of education because they rear children, and men are called upon to instil love for zeal 
(not zeal itself) in women so that they can be the ornament of humanity. ${ }^{73}$ Men, defined by their zeal and honour, were made the active agents of civilization. Later newspapers echo these sentiments. An article in Tamaddun entitled, 'The Liberation of Iran is Entrusted to the Self-Sacrifice of Iranians', written just after the monarchical coup put an end to the first parliament (1908), explicitly addressed itself to 'national brothers' ${ }^{74}$ This exclusivity only began to change with women's participation in the Constitutional Revolution, when they too claimed masculine qualities such as zeal, opening the gendered concept of civility to contestation. ${ }^{75}$

One of Qanun's main projects was for elite reformers and commoners to see themselves unified as participants in the same project of healing the ailing body politic. The elite were to help instil this zeal for reform and devotion to the nation in commoners, so that this work could be undertaken. ${ }^{76}$ The inaugural issue of Qanun calls for the leaders of society-'ulama and men of the pen-to spread the word to the people through schools and pulpits, in the streets and marketplaces, about the benefits of qanun and the need for unity. ${ }^{77}$ They must also instil the meaning of qanun in the men's hearts, so that any sacrifice, even of their lives, will not be beyond them. ${ }^{78}$ Ideals of masculinity were leveraged to bring people to a state of civic participation and patriotic zeal.

Kitab-i Ahmad, by 'Abd al-Rahim Tabrizi Talibov (1834-1911), addressed the wider public that it sought to reform. Though he lived most of his life in the Caucasus, his influential work won him a seat in Iran's first parliamentary elections (1906). ${ }^{79}$ Kitab-i Ahmad was inspired by Jean-Jacques Rousseau's Émile, and is written in the form of daily conversations between the narrator and his young son on a wide range of modern forms of knowledge such as science, religion, politics, and history. From the 1890s, it was used as a textbook in many new schools established in Tehran. ${ }^{80}$ In the preface, Talibov notes that mankind (insan) has been distinguished from wild beasts by the pursuit of enquiry into the causes and truth of things. Talibov presents his work as an introduction to the new sciences and arts in order to increase perception and provide education. He ends by noting that he has written and published this work with the humble hope of reform (islah) for the reader, identified as moral refinement through appropriate education. ${ }^{81}$ This appropriate education was the prerequisite for the rule of law and its ensuing progress, enabling Iran to protect her sovereignty from colonial encroachment.

The way in which knowledge of new arts and sciences was seen to transform the character and comportment of individuals was represented in the title character's own transformation. Each chapter was a day in Ahmad's education, recording what he learned, as well as its effects. Ahmad waits respectfully for his father to speak to him, makes everyone laugh with his witty comments, but laughs himself sparingly. He also accordingly instructs his sister on appropriate instances and volume for laughter when she laughs too loudly in proportion to his joke. ${ }^{82}$ The sister benefits from the moral refinement of male members of the family through outward instruction, but does not herself learn the modern knowledge that enacts substantive transformation.

In a review of Kitab-i Ahmad, Sayyid Asadullah Tabataba'i Nazim al-Dawlah, the chief consul of Iran in Istanbul, introduces the book by invoking islah, whereby 
reading this book 'the common man finds moral refinement (tahzib-i akhlaq) and is educated away from ignorance towards wisdom and perspicacity'. ${ }^{83}$ Talibov is described as having lofty, high-minded aspirations and the book is written so that both young and old can benefit from its wisdom. The inextricability of style and substance is recognized when Tabataba'i notes that, in the expression of complex matters, Talibov has 'carefully observed proper form (adab)', meaning that 'he has written so pleasingly that from reading and hearing the work, any zealous man devoted to the nation will sing the melody of the ecstatic mystic (vajd va sama'-i astin bar afshandah), and acquire hopeful expectations for the future'. ${ }^{84}$ The work of aesthetics thus evokes an ecstatic state-vajd is love as ecstasy and sama' is the ecstasy evoked by music-whose infusion can rectify the deficit of hope. With hope restored, the zealous patriot can work towards bettering the future.

The 1905 Japanese victory over Russia provoked new discussions about the proper ways to maintain Iranian sovereignty in the face of imperial pressures. Japan was seen to have successfully reformed its institutions and joined the ranks of civilized countries without losing its own religion and culture. ${ }^{85}$ In Masa'il al-Hayat (1906) Talibov included a translation and explanation of Japan's Meji constitution. Preceding the translation is a discussion on the nature of law and the need for a constitutional government that is indicative of the relationship between individual equity and just rule, religion, and law. Talibov explains political justice in medical language, as a restoration of the body-politic's humoural balance to bring the state's various parts in harmony according to proper limits. Likewise, the individual needed to have the correct amount of certain qualities in order to achieve equity. In this vein, Talibov describes qanun as the treatment for excess, likening it to the chains required to restrain madness and restore moderation to an individual's disposition: 'Since a person is a limb of the body of society, administering the illness of a single disposition is healing the whole body of society. And if society is not quickly healed of its excesses, it will be the exciter of corruption in all the limbs of civilization.' ${ }^{86}$ Health is a metaphor for the moderation that defines a virtuously ruled society, which is constituted by the equity of its individuals.

The link between the individual and society is the law. Talibov presents divine law (shari'a) as perfect for individuals since it makes manifest the path to God through its well-known limits. At the level of society, its corollary is qanun. ${ }^{87}$ It is complementary to shari' $a$ and moderates the collective disposition because qanun is imbued with the divine law's spirit through 'the imprint of the heavenly words', since 'the sound of society is the sound of God'. But unlike the individual's obedience to shari'a, 'these laws will be followed not because of fear of retribution or hope of forgiveness, but rather from the shame (infíal) of collective attention on the illness of deficiency and intemperance of rebellion'. ${ }^{88}$ Talibov sets adherence to the shari' $a$ as a model for individual virtue, which is transmuted to the realm of society through collective democratic will, ideally manifesting as a constitutional monarchy. Unlike Yusif Khan, Talibov did not justify this form of government according to the Qur'an and Traditions. Rather, qanun itself, because it was the collective will of a shari'a-abiding community, corresponded to the will of God. Justice had become a principle whose form was open, even to the model of a 
country like Japan that did not profess a monotheistic religion. Talibov prefaces the constitution by calling upon all 'homeland-loving and monarch-devoted Iranians to comprehend the meaning of the law and what it means for it to pervade the people's moral refinement (tahzib-i akhlaq)... since where ever there is no law in the land, there is no happiness or prosperity'. The pairing of love of homeland and devotion to the king is an indication of the Japanese constitution's appeal, with its heavy emphasis on the centrality of the emperor (see Chapter 12, Japanese). ${ }^{89}$ At the same time, this was a call for a new kind of Iranian civilization, where Islamic law moulded virtuous individuals to establish a virtuous polity that was both democratic and retained the monarchy.

The quality of zeal, envisioned as the source of strength, virtue, and wealth, linked manhood with the virtues of sovereignty in a global order of nation-states. Colonial domination was linked to a lack of zeal, resulting in a physical and economic weakness that was likened to emasculation. ${ }^{90}$ This weak, indigent, abject manhood defined the lower extreme of acceptable masculinity, while the excesses of its opposite were often characterized as European behaviours. Both colonized and colonizer stood for dishonourable forms of manhood. Talibov's narrator rhetorically marks the behaviours outside the limits of acceptable masculinity by asking, 'what group of wild beasts' engages in the mass slaughter of its own kind? This was a critique of mass, modernized warfare, described as armed aggression across vast battlefields and grotesquely high loss of life. ${ }^{91}$ Such collective behaviour was mirrored in individual behaviour, as Talibov's narrator later asks:

which savage clothes his daughters and women in clothes with low necklines...takes them to a social gathering and gives them over to the embrace of young men for dancing? If the girl adorns herself imperfectly, her mother dismisses her, [saying] 'Sofia or Maria, today you are not so beguiling, the daughter of Mrs. So-and-so appears more beautiful than you.' Such claims of civilization (madaniyat) and honour are a specific, meaning European, [kind of] dishonour (bi-namusi va sharaf) that they know as and call civilization (sivilizatsiun). ${ }^{92}$

By drawing a distinction between Muslim madaniyat and European 'sivilizatsiun', represented as the dishonoured manhood of allowing one's women to be soiled by the gaze of unrelated men, hetero-social customs that Europeans posed as civilization were mocked as behaviour beneath even savages or animals. This is after a spirited promotion of the wonders of European sciences, technologies, and governmental systems, demonstrating the limit according to which madaniyat, posited as masculine honour embedded in a homo-social gendered order, could emulate Europe. ${ }^{93}$ Talibov articulated a modernity that was neither European, colonizing, nor colonized, but one which posed Islam as culture, and was articulated according to a specifically Persian shape in Iran.

Not all modernists agreed with Talibov. Some thought that traditional forms of gender segregation and veiling were impediments to women's, and thus society's, progress. But even Akhundzadah thought a woman should be unveiled only until married, to help facilitate her education, after which she should cover herself, stay indoors, and refrain from socializing with unrelated men in order to protect her 
husband's honour. ${ }^{94}$ Through the constitutionalist period, it was the perceived ignorance and superstition amongst women that was the object of reform, not the homo-social order of society, even amongst women themselves. ${ }^{95}$ Issues around men's appearance were far more contested. Some secular reformers articulated unqualified adoption of European dress, epitomized by shaving of the beard, an uncovered head, and the necktie. For others this adoption was as problematic for men as for women, partly due to different conceptualizations of the relationship between Islam and Iranian civilization. By contrast, namus was overwhelmingly central to modernist concepts of progress and civilization.

The 1912 Russian political ultimatum and military occupation, a series of internal armed conflicts, and the Second World War Allied invasion and occupation of Iran precipitated a shift in reformist discourses. ${ }^{96}$ The language of modern science began to replace older notions of virtue and knowledge as the basis for reform, picking up pace with Pahlavi state-building in the 1920s. ${ }^{97}$

From the mid-nineteenth century, discussions around civilization drew on older Persianate concepts of political justice and individual virtue. Early elite discourses initially emphasized political, legal, and administrative reforms at the level of the state as necessary prerequisites to enable the cultivation of individual equity. In this context, calls for increased zeal were addressed to elites, who would enact these reforms and then lead the way for the masses. Around the turn of the twentieth century, elites began to address a wider population and individuals outside the elite began to participate in the burgeoning public sphere, as mass publishing and political mobilization spread. Rule of law was increasingly proposed as constitutional government, representing a new, nationally conceived, community that required a new kind of civilized citizen. Modernist calls for zeal were made to motivate the pursuit of knowledge in order to obtain perception, which would generate the shame, and love of and devotion to the country, necessary for moral refinement. A constitutional monarchy's rule of law would then be strong enough to resist imperial encroachment externally and chaos internally, manifesting moral refinement.

In spite of women's participation and gendered contestations in mass politics, this moral refinement remained largely masculine and juxtaposed to a despised femininity. Older notions of misogyny were modernized; individual moral refinement was seen to bring the virtue of justice to the body politic through the concept of an explicitly masculine honour. Because the manner of this moral refinement needed to be modern, but not European, honourable manhood depended on the gendered homo-social order of society that came to be defined as the core of Iranian civilization.

\section{NOTES}

1. The term Persian refers to those educated in the Persian language, while the term Iran refers to the kingdom of Iran. This distinction is crucial, because many Persians lived outside the borders of Iran. Persianate is a descriptor of the culture bestowed by such an education. 
2. Ulrich Marzolph, 'A Treasury of Formulaic Narrative: The Persian Popular Romance Hosein-e Kord, Oral Tradition, 14/2 (1999), 279-303. On the role of storytelling in Iranian society, see Mahmoud Omidsalar and Theresa Omidsalar, 'Narrating Epics in Iran', in Margaret Read Mac Donald (ed.), Traditional Storytelling Today: An International Sourcebook (Chicago and London: Fitzroy Dearbon Publishers, 1999), 326-40; Mary Ellen Page, 'Professional Storytelling in Iran: Transmission and Practice', Iranian Studies, 12/3-4 (1979), 195-215. On group reading practices in the constitutional period, see Janet Afary, The Iranian Constitutional Revolution (New York: Columbia University Press, 1996), 117-18.

3. See Afshin Marashi, Nationalizing Iran: Culture, Power, and the State, 1870-1940 (Seattle: University of Washington Press, 2008), 56-65; Monica Ringer, 'Reform Transplanted: Parsi Agents of Change amongst Zoroastrians in Nineteenth-Century Iran', Iranian Studies, 42/4 (2009), 549-60. Noted exceptions are Nile Green, 'Exports for an Iranian Marketplace', in Nile Green, Bombay Islam: The Religious Economy of the West Indian Ocean, 1840-1915 (Cambridge: Cambridge University Press, 2011), 118-54; Mansour Bonakdarian, Britain and the Iranian Constitutional Revolution of 1906-1911: Foreign Policy, Imperialism, and Dissent (Syracuse, NY: Syracuse University Press, 2006).

4. Anna Bryson, From Courtesy to Civility: Changing Codes of Conduct in Early Modern England (Oxford: Oxford University Press, 1998), 193-242.

5. Afsaneh Najmabadi, Women with Mustaches and Men without Beards: Gender and Sexual Anxieties of Iranian Modernity (Berkeley: University of California Press, 2005), 137-8.

6. For a reading of $a d a b$ as a literary humanism containing a moral imagination but without consideration of social ethics, see Hamid Dabashi, The World of Persian Literary Humanism (Cambridge, MA: Harvard University Press, 2012).

7. Ali Akbar Dihkhuda, 'madaniyyat', Lughatnamah-yi Dihkhuda, <http://www.loghatnaameh.org/> accessed 21 January 2013.

8. Dihkhuda, 'madaniyyat'.

9. Ali Akbar Dihkhuda, 'tamaddun', Lughatnamah-yi Dihkhuda, <http://www.loghatnaameh.org/> accessed 21 January 2013.

10. Like many of those with modern secondary educations, Dihkhuda was fluent in French. For greater detail, see A. A. A. Sa'id Sirjani, 'Mirza 'Ali Akbar Dehkhoda Qazvini', Encyclopedia Iranica, vol. 7, fasc. 2, 216-20, <http://www.iranicaonline.org/ articles/dehkoda $>$ accessed 17 February 2013. For more on the development of modern education in Iran, see Monica Ringer, Education, Religion and the Discourse of Cultural Reform in Qajar Iran (Costa Mesa: Mazda, 2001); Maryam Eftikhar, 'Nasir al-Din Shah and the Dar al-Funun: The Evolution of an Institution', Iranian Studies, 34/1-4 (2001), 153-63.

11. For more on Iran's geopolitical situation, see Firoozeh Kashani-Sabet, Frontier Fictions: Shaping the Iranian Nation, 1804-1946 (Princeton: Princeton University Press, 1999); Moritz Deutschmann, “All Rulers are Brothers": Russian Relations with the Iranian Monarchy in the Nineteenth Century', Iranian Studies, 46/3 (2013), 383-413.

12. Mirza Malkum Khan was preoccupied with literacy, see, for instance, his 'Explication of the Introduction of Sa'di’s Gulistan', in Hujjat Allah Asil (ed.), Risalah'ha-yi Mirza Malkum Khan Nazim al-Dawlah (Tehran: Nashr-i Nay, 1381/2002), 416-17; Hamid Algar, 'Malkum Khan, Akhūndzāda and the Proposed Reform of the Arabic Alphabet', Middle Eastern Studies, 5/3 (1969), 116-30. Mirza Yusuf Khan was preoccupied with technological advances like railways. See Mehrdad Kia, 'Constitutionalism, Economic Modernization and Islam in the Writings of Mirza Yusef Khan Mostahsar od-Dowle', 
Middle Eastern Studies, 30/4 (1994), 751-77. For more on some of these debates, see Vanessa Martin, Islam and Modernism: The Iranian Revolution of 1906 (Syracuse, NY: Syracuse University Press, 1989); Ringer, Education, Religion and the Discourse of Cultural Reform, 213-38.

13. See L. Marlow, 'Surveying Recent Literature on the Arabic and Persian Mirror for Princes Genre', History Compass, 7/2 (2009), 523-38; Neguin Yavari, 'Mirrors for Princes or a Hall of Mirrors: Nizām al-Mulk's Siyar al-mulūk Reconsidered', Al-Masaq: Islam and the Medieval Mediterranean, 20/1 (2008), 47-69; Mehrzad Boroujerdi (ed.), Mirror for the Muslim Prince: Islam and the Theory of Statecraft (Syracuse, NY: Syracuse University Press, 2013).

14. This text was first composed and circulated in Azeri Turkish before Akhundzadah translated it into Persian. From the late 1860s it circulated widely as a manuscript in reformist circles. It was published clandestinely in Tehran in 1971 and this version was reprinted as Fath 'Ali Akhundzadah, Maktubat-i Mirza Fath 'Ali Akhundzadah (repr.; n.p.: Intisharat-i Mard-i Imruz, 1985). For more on Akhundzadah, see Mehrdad Kia, 'Mirza Fath Ali Akhundzade and the Call for Modernization of the Islamic World', Middle Eastern Studies, 31/3 (1995), 422-48.

15. Kia, 'Mirza Fath Ali Akhundzade', 9.

16. Kia, 'Mirza Fath Ali Akhundzade', 11.

17. F. Rahman, 'Akhlaq', Encyclopedia Iranica, vol. 1, fasc. 7, 719-23, <http://www.iranicaonline.org/articles/aklaq-ethics-plural-form-of-koloq-inborn-character-moral-character-moral-virtue> accessed 17 August 2012.

18. For more justice, see Amir Arjomand, 'The Salience of Political Ethic in the Spread of Persianate Islam', Journal of Persianate Studies, 1/1 (2008), 5-29.

19. Mirza Malkum Khan, Qanun, 1 and 3, in Mirza Malkum Khan, Ruznamah-i Qanun, ed. Huma Natiq (1890; Tehran: Amir Kavir Publications, 1976).

20. For more on the Constitutional Revolution, see Afary, The Iranian Constitutional Revolution, and Bonakdarian, Britain and the Iranian Constitutional Revolution.

21. For more on his life and work, see Hamid Algar, Mìrzā Malkum Khān; A Study in the History of Iranian Modernism (Berkeley: University of California Press, 1973).

22. Mirza Malkum Khan, 'Daftar-i Tanzimat (Kitabchah-yi Ghaybi)', in Asil, Risalah'ha-yi Mirza Malkum Khan Nazim al-Dawlah, 25.

23. Asil, Risalab'ha-yi Mirza Malkum Khan Nazim al-Dawlah, 26-7.

24. Asil, Risalab'ha-yi Mirza Malkum Khan Nazim al-Dawlah, 27.

25. Asil, Risalab'ha-yi Mirza Malkum Khan Nazim al-Dawlah, 23.

26. For more on Yusif Khan, see Kia, 'Nationalism, Modernism and Islam in the Writings of Talibov-i Tabrizi'.

27. Mirza Yusif Khan Tabrizi, One Word-Yak Kaleme: Nineteenth Century Persian Treatise Introducing Western Codified Law, trans. and ed. Ali Asghar Seyed-Gohrab and Sen Mc Glinn (Leiden: Leiden University Press, 2010), 4-6.

28. Tabrizi, One Word-Yak Kaleme, 6-8.

29. Tabrizi, One Word-Yak Kaleme, 8-12.

30. I thank Afsaneh Najmabadi for suggesting this term.

31. Guity Nashat, The Origins of Modern Reform in Iran, 1870-1880 (Urbana: University of Illinois Press, 1982), 31-2.

32. See Mohamad Tavakoli-Targhi, Refashioning Iran: Orientalism, Occidentalism and Historiography (London: Palgrave, 2001), 86-95, 99-104; Daniel Sheffield, 'In the Path of the Prophet: Medieval and Early Modern Narratives of the Life of Zarathustra in Islamic Iran and Western India', PhD dissertation, Harvard University, Cambridge, MA, 2013. 
33. Akhundzadah, Maktubat-i Mirza Fath 'Ali Akhundzadah, 158-62.

34. Akhundzadah, Maktubat-i Mirza Fath 'Ali Akhundzadah, four of prefacing letter.

35. Malkum Khan noted that Europeans believed that 'the religion of Islam is an obstacle to progress', but he himself contended that 'no faith in the world has engendered progress as has Islam'; see 'Explication of the Introduction of Sa'di's Gulistan', in Asil, Risalab'ha-yi Mirza Malkum Khan Nazim al-Dawlah, 416. The influence of Akhundzadah's views in the nineteenth century have been overemphasized in scholarship seeking genealogies for Pahlavi nationalism. See Marashi, Nationalizing Iran, and Reza Zia-Ebrahimi, 'Self-Orientalization and Dislocation: The Uses and Abuses of the "Aryan" Discourse in Iran', Iranian Studies, 44/4 (2011), 445-72.

36. Nikki R. Keddie, An Islamic Response to Imperialism: Political and Religious Writings of Sayyid Jamäl Ad-Din 'al-Afghānī' (1968; Berkeley: University of California, 1983), 9-11. For more on akhlaqi literature, see Muzaffar Alam, The Languages of Political Islam: India 1200-1800 (Chicago: University of Chicago Press, 2004), 46-69. For a basic overview of Illuminationist thought, see Roxanne Marcotte, 'Suhrawardi', in The Stanford Encyclopedia of Philosophy, ed. Edward N. Zalta (2012 edition), <http://plato. stanford.edu/entries/suhrawardi/> accessed 27 November 2013. For more on Shaykhi thought, see Mangol Bayat, Mysticism and Dissent: Socioreligious Thought in Qajar Iran (Syracuse, NY: Syracuse University Press, 2000), 37-86.

37. For more on pan-Islamist ideas articulated in Persian, see Mehrdad Kia, 'Pan-Islamism in Late Nineteenth-Century Iran', Middle Eastern Studies, 32/1 (1996), 30-52.

38. Keddie, An Islamic Response to Imperialism, 21-2. For more on this encounter, see Aziz Ahmad, 'Sayyid Ahmad Khan, Jamal al-Din al-Afghani and Muslim India', Studia Islamica, 13 (1960), 55-78. For more on al-Afghani, see Keddie, An Islamic Response to Imperialism, 3-35. This book was published in Hyderabad in 1298/1881 (Keddie, An Islamic Response to Imperialism, 192) and was translated into Arabic by Muhammad 'Abduh, as 'Refutation of the Materialists' (Keddie, An Islamic Response to Imperialism, 54-5).

39. Saiyid Jamal ad-Din 'al-Afghani', 'The Truth about the Neicheri Sect', in Keddie, An Islamic Response to Imperialism, 148.

40. Keddie, An Islamic Response to Imperialism, 141-2.

41. Keddie, An Islamic Response to Imperialism, 142-3.

42. Keddie, An Islamic Response to Imperialism, 144-5.

43. Wide-ranging figures such as the modern Darwin (Keddie, An Islamic Response to Imperialism, 135-7), the medieval Fatimid Isma'ilis (156) and the pre-Islamic Persian heretic Mazdak (155) are called Naychirists.

44. The text was first lithographed in Bombay in 1299 [1882], reissued in 1310 [1892/93], and subsequently printed in 1911 in Cairo. All citations are from 'Abd al-Baha, Risälah-yi madaniyah va Risälah-'i siyāsīyah (Darmstadt: 'Asr-i Jadd, 2006). Also see the interpretive translation: 'Abd al-Baha, The Secret of Divine Civilization, trans. Marzieh Gail (Wilmette: Bahái Pub. Trust, 1957).

45. For instance, in an intertextual reference to al-Tahtawi, 'Abd al-Baha reinterprets the story of the pre-Islamic Arab King Nu'man (Baha, Risälah-yi madanīyah va Risälah-'i siyāsiyah, 38-41).

46. Baha, Risālah-yi madaniyah va Risālah-'i siyäsīyah, 61. This is where he cites Draper as an example. 'Abd al-Baha transliterates his name as 'Dray-bar', titles his work 'Taraqqiyi Umam [Progress of peoples]' and calls him French, which may be the language in which he encountered the work. He was likely drawing from Draper's The History of the Intellectual Development of Europe (1862). See Baha, The Secret of Divine Civilization, 92, n. 53. 
47. 'Abd al-Baha, Risālah-yi madaniyah va Risālah-'i siyāsīyah, 13. For more on these efforts, see Nashat, The Origins of Modern Reform in Iran.

48. For more on 'Abd al-Baha and his influences, see Juan R. I. Cole, Modernity and the Millennium: The Genesis of the Bahai Faith in the Nineteenth-Century Middle East (New York: Columbia University Press, 1998), 79-82 and passim; Moojan Momen, 'The Bahai Influence on the Reform Movements of the Islamic World in the 1860s and 1870s', Baha'i Studies Bulletin, 2/2 (1983), 47-65.

49. 'Abd al-Baha, Risālah-yi madanīyah va Risälah-'i siyāsiyah, 15-17.

50. 'Abd al-Baha, Risālah-yi madanīyah va Risālah-'i siyāsīyah, 32-4.

51. 'Abd al-Baha, Risālah-yi madanīyah va Risālah-'i siyāsīyah, 42.

52. 'Abd al-Baha, Risālah-yi madanīyah va Risālah-'i siyäsīyah, 44-5.

53. 'Abd al-Baha, Risālah-yi madanīyah va Risālah-'i siyāsīyah, 16.

54. Issues 1 and 3 in Malkum Khan, Ruznamah-i Qanun.

55. For more on Comte's thought, see Michel Bourdeau, 'Auguste Comte', in The Stanford Encyclopedia of Philosophy, ed. Edward N. Zalta (2011 edition), <http://plato.stanford. edu/archives/sum2011/entries/comte/> accessed 27 November 2013.

56. Commonly interpreted by scholars as misinterpretations or contradictions, analysis of this selection and interpretation is central to understanding conceptual change. For an articulation of this in the Indian case, see Benjamin Zachariah, 'Notes on the Chase', in Joachim Kurtz and Martin Hofmann (eds.), Knowledge on the Move (forthcoming).

57. Martin, Islam and Modernism, 27-33.

58. Bahais and Azalis both grew out of the Babi Movement and, after the mid-1860s, were distinct and antagonistic groups. But there is confusion in nineteenth-century sources about who is meant by the appellation 'Babi'. After 1870s, 'Babis' were usually a reference to Bahais. See Momen, 'The Bahai Influence on the Reform Movements of the Islamic World'.

59. For more on the Babi Movement, see Abbas Amanat, 'The Historical Roots of the Persecution of the Babis and Baha' is in Iran', in Dominic Brookshaw and Seena Fazel (eds.), The Baha'is of Iran: Socio-Historical Studies (London: Routledge, 2008), 170-83.

60. Hamid Algar, 'Introduction to the History of Freemasonry in Iran', Middle Eastern Studies, 6 (1970), 283.

61. Maryam B. Sanjabi, 'Rereading the Enlightenment: Akhundzada and his Voltaire', Iranian Studies, 28/1-2 (1995), 48-9.

62. Akhundzadah, Maktubat-i Mirza Fath 'Ali Akhundzadah, 3.

63. Sanjabi, 'Rereading the Enlightenment', 52.

64. Mirza Malkum Khan, 'Persian Civilisation', Contemporary Review, 59 (1891), 239.

65. For more on the rearticulation of concepts such as honour and nation, to which gender is central, see Najmabadi, Women with Mustaches and Men without Beards.

66. Akhundzadah, Maktubat-i Mirza Fath 'Ali Akhundzadah, four of prefacing letter.

67. Najmabadi notes that 'national sovereignty and masculine honor became the simultaneous prizes of changed political regime'. Najmabadi, Women with Mustaches and Men without Beards, 216.

68. For more see, Keddie, An Islamic Response to Imperialism.

69. The importance of Qanun is difficult to overestimate. Important Revolution-era newspapers of various political stripes reprinted Malkum Khan's articles, praised his writings, and explicitly invoked Qanun as inspiration. Algar (1973), 247-8; Edward G. Browne, Press and Poetry of Modern Persia: Partly Based on the Manuscript Work of Mirza Muhammad Ali Khan Tarbiyat of Tabriz (Cambridge: Cambridge University Press, 1914), 116. 
70. Issue 16, 1 in Malkum Khan, Ruznamah-i Qanun.

71. Najmabadi, Women with Mustaches and Men without Beards, 1-2, 97-129.

72. Issue 16, 1 in Mirza Malkum Khan, Ruznamah-i Qanun.

73. Issue 13, 4 in Malkum Khan, Ruznamah-i Qanun; Najmabadi, Women with Mustaches and Men without Beards, 211-22.

74. Mirza Malkum Khan, 'The Liberation of Iran is Entrusted to the Self-Sacrifice of Iranians', Tamaddun, 5 Ramadan 1326 [21 October 1908], 1.

75. Najmabadi, Women with Mustaches and Men without Beards, 222-31.

76. Issue 38, 2-3 in Mirza Malkum Khan, Ruznamah-i Qanun.

77. Issue 1, 3 in Malkum Khan, Ruznamah-i Qanun.

78. Issue 4 in Malkum Khan, Ruznamah-i Qanun.

79. For more on Talibov, see Mehrdad Kia, 'Nationalism, Modernism and Islam in the Writings of Talibov-i Tabrizi', Middle Eastern Studies, 30/2 (1994), 201-23; Ringer, Education, Religion and the Discourse of Cultural Reform, 231-8.

80. Ringer, Education, Religion and the Discourse of Cultural Reform, 231.

81. 'Abd al-Rahim ibn Abu Talib ibn 'Ali Murad Najar Talibov Tabrizi, Safina-i Talibi, ya Kitab-i Ahmad (Istanbul: Akhtar, 1311 [1893/94]). The preface is unpaginated but is two pages directly after the table of contents, $\mathrm{i}-\mathrm{ii}$.

82. Tabrizi, Safina-i Talibi, ya Kitab-i Ahmad, 5-9.

83. Asadullah Tabataba'i, 'Afterword', in Tabrizi, Safina-i Talibi, ya Kitab-i Ahmad, 239.

84. Tabataba'i, 'Afterword', 239-40.

85. Abbas Amanat, 'Constitutional Revolution, i. Intellectual Background', in Encyclopaedia Iranica (New York: Columbia University, 1992), <http://www.iranicaonline. org/articles/constitutional-revolution-i> accessed 27 November 2013; Ringer, Education, Religion and the Discourse of Cultural Reform, 230.

86. 'Abd al-Rahim ibn Abu Talib ibn 'Ali Murad Najar Talibov Tabrizi, Masa'il al-Hayat (Tiflis: Matba'i Ghayrat, 1324 [1906]), 136.

87. Tabrizi, Masäil al-Hayat, 135-6.

88. Tabrizi, Masail al-Hayat, 137.

89. Tabrizi, Masäil al-Hayat, 137-51.

90. Tabrizi, Masäil al-Hayat, 36.

91. Tabrizi, Masa’il al-Hayat, 35.

92. Tabrizi, Masäil al-Hayat, 36.

93. Najmabadi, Women with Mustaches and Men without Beards, 135-6.

94. Akhundzadah, Maktubat-i Mirza Fath 'Ali Akhundzadah, 177-8.

95. Najmabadi, Women with Mustaches and Men without Beards, 134-7.

96. Afary, The Iranian Constitutional Revolution, 314-42.

97. Cyrus Schayegh, Who is Knowledgeable, is Strong: Science, Class, and the Formation of Modern Iranian Society, 1900-1950 (Berkeley: University of California Press, 2009), 13-17. 
